$\$=-$ 国

\title{
Wetland as revitalization pond at urban area based on the eco hydrology concept
}

\author{
M. Adek Rizaldi ${ }^{1}$ *, Lily Montarcih Limantara ${ }^{2}$ \\ ${ }^{1}$ Directorate of Dam Operational and maintenance, Ministry of Public Works and Housing, Jakarta, Indonesia Water Resources En- \\ gineering, Faculty of Engineering, Brawijaya University, Malang \\ ${ }^{2}$ Water Resources Engineering, Faculty of Engineering, Brawijaya University, Malang, Indonesia \\ *Corresponding author E-mail: adek.rizaldi@yahoo.com
}

\begin{abstract}
Universitas Indonesia (UI) has a campus in Depok with six ponds, five of which are artificial ponds and one of the catchment area that operates in the central Ciliwung Sub-watershed. The ponds (Kenanga, Agathis, Mahoni, Puspa, Ulin and Salam "KAMPUS") are designed as one of the catchment area, referring to Presidential Decree No. 32/1990 about the management of protected areas, ponds as catchment areas, flood controllers, and groundwater runoff. However, due to uncontrolled development in the catchment area of the UI pond system, KAMPUS cascade ponds transformed into a "toilet" which accommodates the liquid and solid waste of its catchment area. The mechanism designed for management in the KAMPUS cascade pond system is to utilize the cascade pond as a stabilization pond (improving water quality). One of them is utilizing Agathis cascade pond as a constructed stormwater wetland system, which is a pretreatment for the inflow to the KAMPUS pond system. This constructed wetland design is planned with several mechanisms: precipitation, filtering, chemical process by utilizing plants for absorption, nutrient transformation and eliminating pathogens. The result shows that this constructed wetland gives the water quality improvement percentage up to $87 \%$. Water quality on effluent conforms with the water quality standards for irrigation and planting (grade 4) referring to Government Regulation No. 82/2001 about Water Quality Management and Pollution Control.
\end{abstract}

Keywords: KAMPUS Cascade Pond; Constructed Wetland; Pond Management; Water and Environmental Quality; Water Quality Standard.

\section{Introduction}

Universitas Indonesia (UI) is the only university in Indonesia ranked 79th of the top 100 best universities in Asia [1] and ranked $62 \mathrm{nd}$ of the best universities in the World by UI-Green Metric [2]. UI campuses are located in Salemba and Depok. UI campus in Depok has six cascade ponds, five of which are artificial cascade ponds. The six cascade ponds are named K.A.M.P.U.S which stands for Kenanga-Agathis-Mahoni-Puspa-Ulin-Salam, names of Indonesian endemic trees [3].

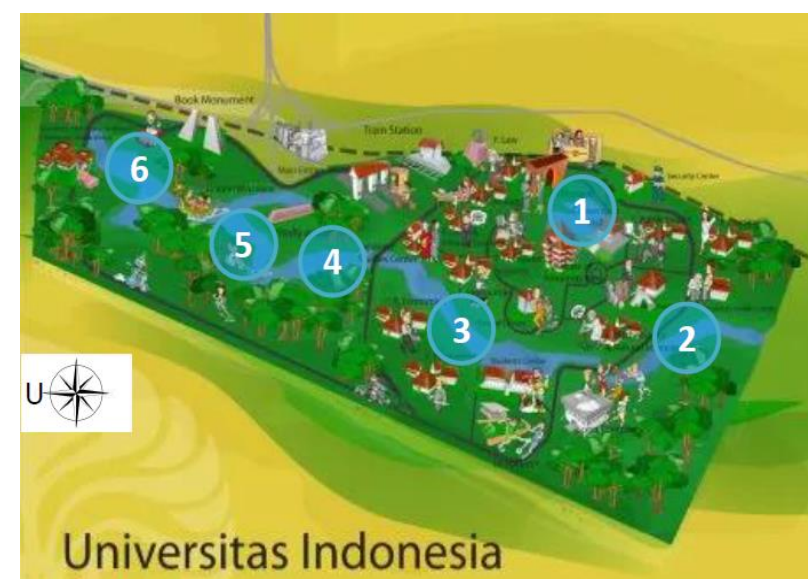

Fig. 1: UI Campus, Depok.
Table 1: UI Depok Campus Ponds

\begin{tabular}{llll}
\hline No. & Name & Area $\left(\mathrm{m}^{2}\right)$ & Established in the year \\
\hline 1. & Kenanga & 28.000 & 1992 \\
2. & Agathis & 20.000 & 1995 \\
3. & Mahoni & 45.000 & 1996 \\
4. & Puspa & 20.000 & 1995 \\
5. & Ulin & 72.000 & 1998 \\
6. & Salam & 42.000 & 1998 \\
& Total & 227.000 & \\
\hline
\end{tabular}

UI cascade pond system, established in the 90 s, is designed as part of educational and recreational facilities, as well as water catchment area. As an educational facility, UI pond serves as a support tool for academic community research. As recreational facility, especially Salam and Kenanga cascade pond, they are often visited by both UI academic community and neighborhood. While as a water catchment area, referring to the Presidential Decree No.32/1990 about the management of protected areas, the ponds are acting as catchment areas, flood controllers, and groundwater runoff.

After approximately twenty years since the cascade ponds were established along with the poorly planned development of Depok city, UI cascade pond is almost transformed into a massive garbage dump, with water quality continuously declining, and contaminated by various pollutants from its catchment area [3].

To improve the existing water condition on KAMPUS cascade pond, the collaborative rescue plan, water health audit has been conducted for water catchment area UI pond in 2016 and produced information of KAMPUS pond conditions. Assessment of water conditions based on recommendations from the Center for Watershed Protection, requires information of the percentage of impervious land cover. 


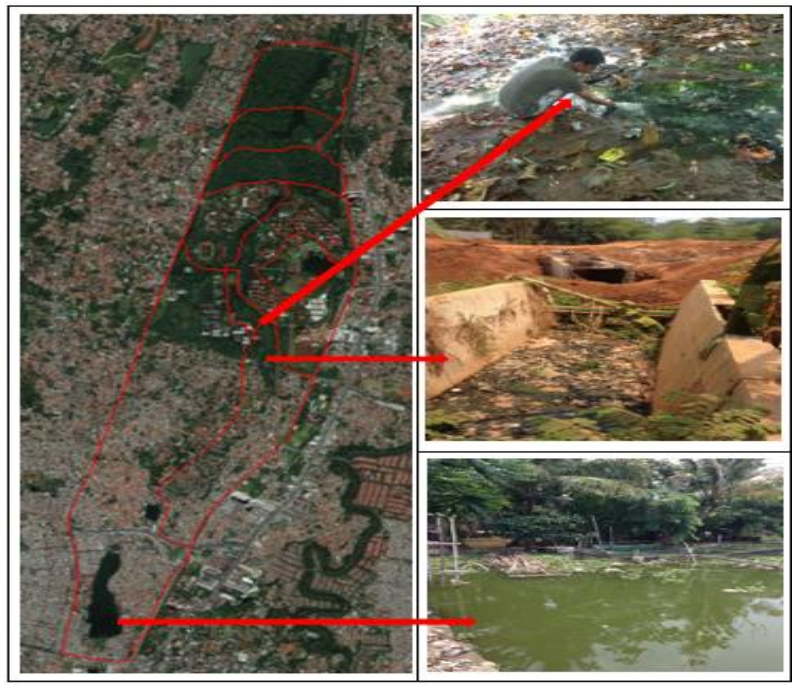

Fig. 2: Catchment Area of UI Ponds and their Surroundings.

Based on the result of measurement of catchment area UI Depok Campus and impervious land cover map, it is known that the percentage of impervious land cover is $60 \%$. The research from Center for Watershed Protection (CWP) in 2003 [4] indicates that the condition of catchment area KAMPUS pond is already in damaged condition with obvious decreasing water quality, especially in Agathis cascade pond, which is directly related to the sub-system outside UI Campus.

The purpose of this paper is to provide proposed management of cascade pond in urban area based on the ecohydrology concept by utilizing constructed wetland technology. The constructed wetland method will be applied to Agathis cascade pond with the aim of improving the water quality, restoring biotic integrity and making the landscape elements of UI Depok Campus.

\section{Methodology}

Wetland is an intermediate area between land and water bodies Characteristics of wetland both natural and constructed according to United State Department of Agriculture (USDA, et al., 1995) is the availability of surface water in the area on a regular basis. Hydrologically, the stream present in wetlands is generally a stream with low velocity, shallow water and saturated soil conditions. Agathis cascade pond Constructed Wetlands are designed, planned, manufactured and operated to deliver various purposes. In accordance with its philosophy and approach, Constructed Wetlands are multi-purposely made, such as for waste treatment, provision of habitat and wildlife diversity, supporting recreational activities, storing water during the dry season, and adding aesthetic value to the environment [5].

Implementation of Constructed Wetland Technology has not been popular in Indonesia because the studies and publications are still lacking. Constructed Wetland is one of the water waste treatment solutions that rely on the roots of aquatic plants (swamp plants) for filtration, medium and bacteria to treat various water waste such as BOD, SS, pathogenic bacteria, nutrients and heavy metals. Constructed Wetland is an effective, inexpensive and easy maintenance technology [6].

Constructed wetland development on Agathis cascade pond is designed with more controlled treatment, by setting Hydraulic Retention Time (HRT) and Hydraulic Loading Rate (HLR) [7] to consider its dimensions. From the hydraulic aspect it can be classified into Constructed Wetlands with Free Water Surface (FWS) and Sub Surface Flow (SSF). Based on flow patterns, Constructed Wetlands can be classified according to horizontal and vertical flow directions [7].

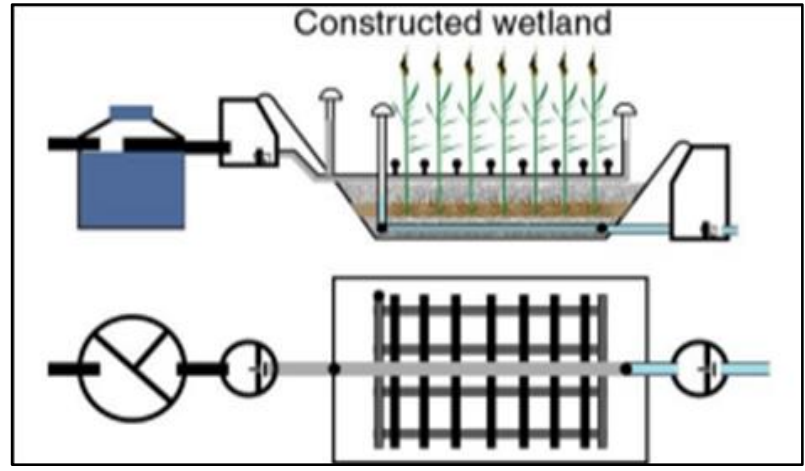

Fig. 3: Constructed Wetland with Horizontal Flow Pattern (HSSF).

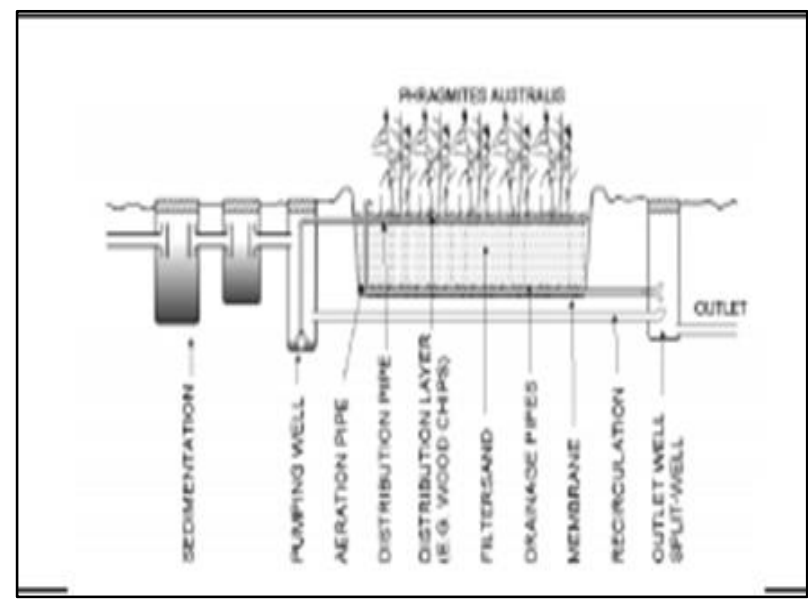

Fig. 4: Constructed Wetland with Vertical Flow Pattern (VSSF)

The pollutant reduction mechanism designed in constructed wetland is carried out by physical, chemical and biological processes as listed in table below:

Table 2: Pollutants and their Respective Process in Wetland

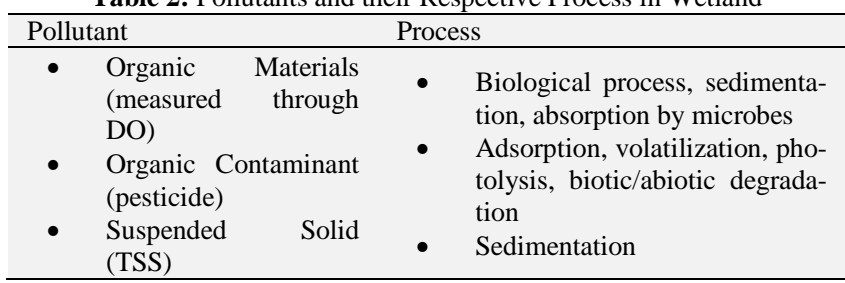

Water management systems in this wetland system are affected by climate and weather, hydroperiod, hydraulic residence time, loading rate, groundwater exchange, and ET [8]. Wetland water balance calculations for FWS Constructed Wetland are shown in Equation below [9]:

$\frac{d V_{w}}{d t}=Q_{i}+Q_{c}+Q_{s m}-Q_{o}-Q_{b}-Q_{g w}+(P-E T) A_{w}$

Where $V_{w}$ is the water volume or storage in wetland $\left(\mathrm{m}^{3}\right) ; t$ is time (day); $Q_{\mathrm{i}}$ is the level of water waste inflow $\left(\mathrm{m}^{3} / \mathrm{d}\right) ; \mathrm{Q}_{\mathrm{c}}$ is the catchment area runoff discharge $\left(\mathrm{m}^{3} / \mathrm{d}\right) ; \mathrm{Q}_{\mathrm{sm}}$ is melting snow discharge $\left(\mathrm{m}^{3} / \mathrm{d}\right) ; \mathrm{Q}_{0}$ is outflow discharge $\left(\mathrm{m}^{3} / \mathrm{d}\right) ; \mathrm{Q}_{\mathrm{b}}$ is the berm loss rate $\left(\mathrm{m}^{3} / \mathrm{d}\right) ; \mathrm{Q}_{\mathrm{gw}}$ is the soil infiltration $\left(\mathrm{m}^{3} / \mathrm{d}\right) ; \mathrm{P}$ is the rainfall $(\mathrm{m} / \mathrm{d})$; ET is the evapotranspiration $(\mathrm{m} / \mathrm{d})$; and $A_{w}$ is the wetland water surface area $(\mathrm{m} 2)$. In this design, groundwater, or discharge $\left(\mathrm{Q}_{\mathrm{gw}}\right)$, berm loss rate $\left(\mathrm{Q}_{\mathrm{b}}\right)$ and $\left(\mathrm{Q}_{\mathrm{sm}}\right)$ melting snow discharge are negligible and the system is assumed to be steady state.

Water demand in wetlands are calculated by considering the dimensions of wetland, depth of design, porosity of soil medium and resident time. The water discharge demand to irrigate this wetland is $0.0043 \mathrm{~m}^{3} / \mathrm{s}$ or about 4.3 liters $/ \mathrm{sec}$. 


\section{Results}

In the Agathis Constructed Wetland design, the water waste (gray water) enters the trash trap and sedimentation basin, so that the water is free of debris and the amount of incoming sediments has decreased significantly. Out of the sedimentation pool, water enters through the channel into Pool A. This pool serves as a controller for the discharge that enters the Wetland, and pool A also has a "by pass" channel to pass water in the rainy season. Based on the speed of water enters through the wetland, it can be known that the resident time in wetland is 10 days. Pollution removal is calculated based on the area of wetland, temperature, and flow rate in wetland using the following equation.

$$
\mathrm{A}_{\mathrm{W}}=\left(\frac{0.0365 \cdot \mathrm{Q}}{\mathrm{K}_{\mathrm{A}}}\right) \cdot \ln \left(\frac{\mathrm{c}_{1}-\mathrm{c}^{*}}{\mathrm{c}_{\mathrm{e}}-\mathrm{c}^{*}}\right)
$$

where $A_{-}$w is the required area (ha); $Q$ is the water discharge; $C_{-} \mathrm{i}$ is the inflow concentration $(\mathrm{mg} / \mathrm{L}) ; \mathrm{c}^{\wedge *}$ is the background concentration $(\mathrm{mg} / \mathrm{L})(1.0$ BOD and TSS); and C_e is outflow concentration $(\mathrm{mg} / \mathrm{L}) ; \mathrm{K} \_\mathrm{a}$ is the first temperature-dependent constant of the first order of the area at temperature T. $K \_$a can be calculated using the following equation.

$\mathrm{K}_{\mathrm{A}}=\mathrm{K}_{\mathrm{A}, 20} \cdot \theta^{(\mathrm{T}-20)}$

Where $\mathrm{K}_{\mathrm{A}, 20}$ is the first-order constant of the area at $20^{\circ} \mathrm{C}$, and $\theta$ is the design parameter.

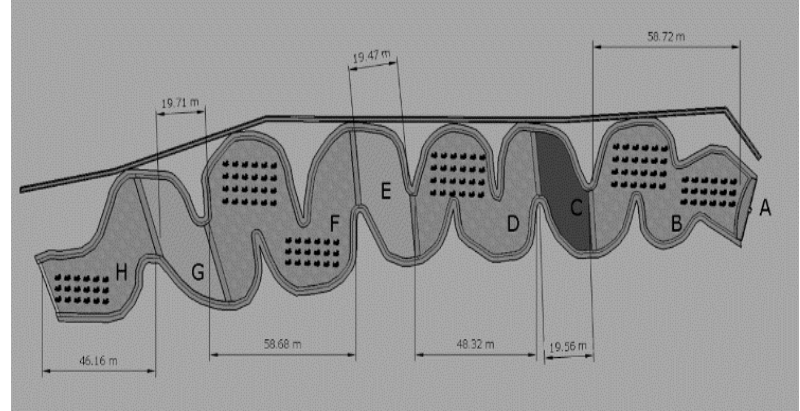

Fig. 5: Plan View of Agathis Stormwater Constructed Wetland.

In the calculation of Table 2, it can be seen that the effluent concentration of Agathis Stormwater Constructed Wetland conforms with the Class 4 Water Quality Standard.

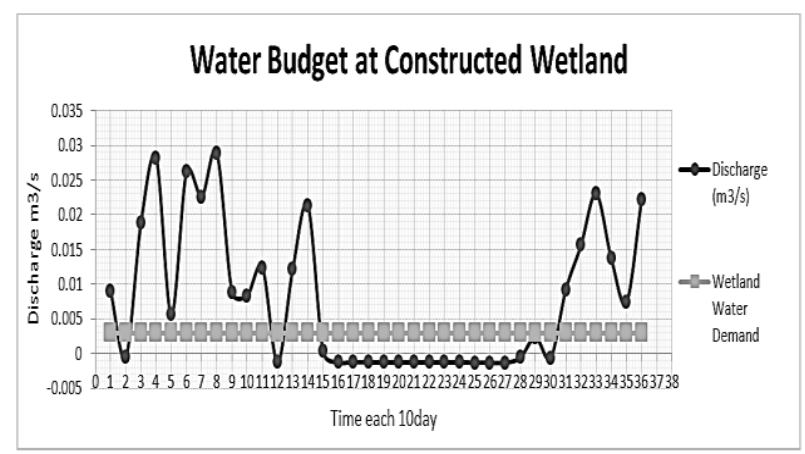

Fig. 6: Discharge and Wetland Water Demand over the Days.

Table 3: Pollutant Removal of Agathis Constructed Wetland

\begin{tabular}{|c|c|c|c|c|c|c|c|c|c|c|c|}
\hline Pollutant & $\begin{array}{l}\mathrm{Ci} \\
(\mathrm{ppm})\end{array}$ & $\begin{array}{l}\mathrm{Ce} \\
(\mathrm{ppm})\end{array}$ & $\begin{array}{l}\text { Water Quality } \\
\text { Standard } \\
\text { (Grade 4) }\end{array}$ & $\%$ Removal & $\mathrm{K}_{20}$ & $\begin{array}{l}\mathrm{T} \\
\left({ }^{\circ} \mathrm{C}\right)\end{array}$ & $\theta$ & $\mathrm{Ka}$ & $\begin{array}{l}\text { Qav } \\
\left(\mathrm{m}^{3} / \mathrm{d}\right)\end{array}$ & A (ha) & $\mathrm{A}\left(\mathrm{m}^{2}\right)$ \\
\hline BOD & 17.48 & 1.20 & 12 & 93.15 & 34 & 29 & 1 & 34 & 259.10 & 0.7455 & 7455.18 \\
\hline COD & 50 & 3.43 & 100 & 93.15 & 34 & 29 & 1 & 34 & 259.10 & 0.7455 & 7455.18 \\
\hline TSS & 96 & 0.39 & 400 & 99.60 & 70 & 29 & 1 & 70 & 259.10 & 0.7455 & 7455.18 \\
\hline Nitrat N & 1 & 0.13 & 20 & 87.49 & 17 & 29 & 1.05 & 26.37 & 259.10 & 0.7455 & 7455.18 \\
\hline $\mathrm{TP}$ & 12.8 & 4.97 & 5 & 61.17 & 12 & 29 & 1 & 12 & 259.10 & 0.7455 & 7455.18 \\
\hline Fecal Coli (cfu/100ml) & 2200 & 139.37 & 2000 & 93.67 & 35 & 29 & 1 & 35 & 259.10 & 0.7455 & 7455.18 \\
\hline
\end{tabular}

\section{Conclusion}

This design demonstrates the feasibility of Stormwater Constructed Wetland for domestic (gray water) water waste treatment in Universitas Indonesia. This Wetland not only improves the quality of water waste but also stores large amounts of water that can be used for other purposes such as plant watering. The result shows that the level of pollutants in the water waste can be reduced to $61 \%$ after 10 days in the area of 0.745 ha of constructed wetland system.

Wetland needs water to continue throughout the year with a constant discharge of $0.0034 \mathrm{~m} 3 / \mathrm{s}$ or about 3.4 liters/second including the calculation of water lost due to evapotranspiration.

\section{References}

[1] QS University Rankings Asia QS TOP UNIVERSITIES Asia [Online]. - 2015. - http://www.topuniversities.com/university rankings/asian-university-rankings/2015.

[2] QS World University Rankings [Online]. - 2015. http://www.topuniversities.com/university-rankings/world-university-rankings/2015.

[3] BP3U-PAU Badan Perencanaan, Pengembangan dan Pengendalian Universitas Laporan Pre-Audit Danau KAMPUS [Report]. - Depok: Universitas Indonesia, 2015.

[4] CWP Center for Watershed Protection Watershed Vulnerability Analysis [Report]. - 2003.
[5] Greg, W., Young, R. N., Brown, M. Constructed Wetland Manual, Volume 1. Department of Land and Water Conservation, University of New South Wales, Australia. 1998.

[6] Dallas S, Scheffe B, Ho G. Reedbeds for greywater treatment case study in Santa Elena-Monteverde, Costa Rica, Central America. Ecol. Eng., 23(1): 55-61. 2004.

[7] Vymazal, J. Constructed Wetlands for Wastewater Treatment. Water 2, 530-549. 2010.

[8] USDA Natural Resources Conservation Service, EPA-Region III US Environmental Protection Agency and Pennsylvania Department of Environmental Resources A HANDBOOK OF CONSTRUCTED WETLANDS [Book]. - Pennsylvania [s.n.], 1995.

[9] Kadlec and Knight. Treatment Wetlands. First Edition, CRC Press, Boca Raton, Florida. 1996. 